\title{
The African Union and Conflict Management ${ }^{1}$
}

\author{
Isaac Olawale Albert*
}

\begin{abstract}
This paper reflects on the ability of the African Union (AU) to implement its conflict management mechanism. The response of the AU to the 'military coup' in Togo and its mission in Sudan are used as case studies. The emerging picture is that African leaders are now alive to their responsibilities for making, building and keeping peace in Africa. African leaders know that the days of non-interference and expecting the rest of the world to resolve conflict situations created by them are over. The AU would, however, achieve better results if the member states are more committed to removing the problems faced by the organisation. The most salient include the poor commitment of some African leaders to positive peace, the regional organisation is still as under funded as the former OAU, and the problem of weak national armies in some member states compromises efficiency of peace support operations.
\end{abstract}

\section{Résumé}

Ce papier examine les capacités de l’Union africaine (UA) à mettre en œuvre son mécanisme de résolution des conflits. La réaction de l’UA au « coup d'état militaire » survenu au Togo, et sa mission au Soudan constituent ici des études de cas. L'image qui en ressort est que les dirigeants africains sont désormais devant leurs responsabilités de réaliser, édifier et maintenir la paix en Afrique. L’époque où les dirigeants africains s’attendent le reste du monde assainir situations des conflits que certains d'entre eux ont créés semble révolue. Cependant, l'UA réussirait mieux si les États membres s'engageaient davantage dans la résolution des problèmes auxquels l'organisation est confrontée. Le plus frappant

* Dr. Isaac Olawale Albert is at the Peace and Conflict Studies Programme, Institute of African Studies, University of Ibadan, Ibadan, Nigeria. Email: ioalbert2004@yahoo.com 
reste le faible engagement de certains dirigeants africains pour une paix positive, l'organisation régionale reste aussi sous-financée que l'ex-OUA, et le problème de la faiblesse des armées nationales de certains États membres rend moins efficaces les opérations d'appui à la paix.

\section{Introduction}

The topic of this paper can be approached from a plethora of perspectives. By far, the easiest is to do a diachronic analysis of the achievements of the African Union in conflict management. We have some reservations about this easy approach. The AU is a baby that is still living on milk. It has started growing teeth, but the teeth are not yet strong enough to break the kind of bones available in the challenging post cold war global environment in which it is expected to survive. What some leaders of the continental organization sometimes refer to as the achievements of the AU strikes the serious analyst more as a wake up call to duty than any serious attainment. In other words, whereas it is possible for African leaders to engage in self-immolation about the $\mathrm{AU}$, it is dangerous for an academic analyst to tread the same path without taking time to ensure that what he considers to be a 'system' today is actually not a mirage that will soon fade out with time. What nobody can deny is that the AU is still 'test running' its systems. Our attitude to the activities of the organization is thus that of 'wait-and-see'. In essence, it is too early to begin to make conclusive statements about the 'achievements' of the body.

We are therefore challenged to look toward some other directions in identifying the analytical approach to adopt in engaging the subject-matter of this paper. What we decided to do is to contextualize the formation of the AU and problematise the post-cold war political space within which the regional organization is expected to manage intra-state conflicts in Africa. This approach puts our African experience in a global perspective and promises to empower the reader with sufficient information for reaching their individual conclusions on the attainment of the AU, what it is expected to have attained, what the regional organization is and what it is not able to do as far as conflict management in Africa is concerned.

\section{Conceptual framework}

A number of concepts used in this paper have to be defined from the outset. These concepts include conflict prevention, preventive diplomacy, conflict settlement, conflict management, conflict resolution, peace-making and peacebuilding. What does each of them mean?

Of all the concepts named above, the broadest and perhaps the most controversial is 'conflict resolution'. We therefore take it first. Conflict reso- 
lution is an omnibus concept that covers a number of academic, activist, military and diplomatic understandings of how a conflict can be peacefully terminated. It involves 'building bridges between hostile communities, working to clarify issues which represent points of confrontation between them, and creating opportunities for developing new relationships based upon a process of peaceful change and grass-root level reconciliation' (International Alert 1995). Conflict resolution, according to Maluwa (1989:310) involves 'Changing reality either by reducing scarcity of a disputed value or resource, or by changing the causal factors that have made for antagonism and confrontation in the past. It can also consist of changing the demands of the conflict actors so that a distribution of values is found that is subjectively acceptable to both of the actors and therefore agreed'.

Conflict resolution is considered by many peace scholars to be a very ambitious goal to set for oneself. Conflicts are difficult to resolve in the true sense of the word. They are thus better managed or prevented altogether. Scholars who are wary of using the concept of 'conflict resolution' argue that conflict incidents may be solved, but conflict per se is never solved. Each solution creates, in a Hegelian sense, a new plateau or a new synthesis against which the next conflict scenario is played. Society never 'solves' conflict totally. Conflict incidents or episodes are solved and then re-solved and re-solved'.

Kenneth E. Boulding, who with Robert Cooley Angell invented the concept of 'conflict resolution', shifted grounds some years later to become an advocate of another concept: 'conflict management' (1990:36-7). He thus argued that 'perhaps conflict should not be, resolved, but should be managed, at least to maximize the total gain to both parties, no matter the distributional outcome...It is an attempt to derive what might almost be called a "minimum normativeness"'. To say a conflict can be resolved is to pretend that a person would be divested of all elements of his life that triggered the conflict in the first place. It is easier to urge disputants to 'manage' their problems so that they do not escalate into violence. This line of reasoning is agreeably reinforced by the analysis of Woodhouse (1994), Gurr (1995) and Rupersinghe (1995) when they equally noted that conflict is not a static phenomenon in any situation. It changes from the latent to manifest stage and from escalation stage to that of de-escalation. The problem can only dealt with within their individual contextual cyclical processes. Conflict can therefore become transformed from the positive stage to the negative if not well managed and vice versa and dealt with within such contexts. It is therefore better to talk of 'managing' the problem so as to prevent it from becoming a manifest problem and where it has escalated (especially into physical violence) to constructively de-escalate it. 
The existing literature suggests that most peace scholars take both conflict resolution and conflict management to mean the same thing. This is suggested by how the concepts are interchangeably used and is freely evident in the work of Marc Ross (1993:39) who has a major work on The Culture of Conflict. For example, he noted:

The way conflict is managed depends on whether the society has a reinforcing as opposed to cross-cutting social structure. In societies with reinforcing social structure, conflict is expansive and difficult to resolve for several reasons: the mobilization of others in one's core group is relatively easy, there are few people whose interests hinge on the resolution of the dispute, and conflict may persist unless a common external foe forces disputants to resolve their differences. In contrast, individuals in cross-cutting ties societies cannot count on a large, loyal core group who share the same interests, because people mobilized on the basis of one shared characteristic, like kinship, can oppose each other over another, such as residence or ritual affiliation. Ties among members of same community and among different communities limit the severity of overt conflict and promote dispute settlement through shared interests.

The concept of 'dispute settlement' introduced above has to be put in its proper perspective. It is not a synonym for either conflict resolution or conflict management. It means something different. Anthony de Reuck (1985: 15) provides an insight:

'Settlement' has the connotation of determination by a third party such as a court or a greater power. It could be a compromise which the parties feel they have no option but to accept. 'Resolution', on the other hand, implies a solution freely acceptable to all parties, one that does not sacrifice any of their important values, one that parties will not wish to repudiate when they recover the strength to do so. In effect, settlement merely reduces the level of intensity of conflict behaviour, possibly to zero; whereas resolution removes the very ground of conflict, and eliminates or transforms the conflict situation. Only when conflict is resolved, as distinct from settled, is the outcome selfsupporting in the sense that it is positively advantageous to all concerned.

In some other literature, it is also possible to see some scholars using 'conflict regulation'. This concept suggests to me the use of force in bringing about peace; though the 'force' indicated here could be purely legal not necessarily military in nature. A regulated conflict might not necessarily generate a peaceful environment. It is more likely to produce a win-lose outcome between disputants. A number of other questions will suggest to us the kind of problems that are likely to be associated with conflict regulation: Who sets out the terms of conflict regulation; Who has the power to enforce such regulation? How does such a person go about performing this task? 
This probably explains why conflict regulation is not commonly found publications on peace. Some scholars however use it to refer to situations where policy-makers put together a body of laws aimed at preventing people from getting into violent conflict. This is a mere wishful thinking.

All the concepts have specific relevance to a peace process. Writing on relationship between them, Lake (1993: 27) noted:

...advocates of conflict resolution would prefer an approach that allows the parties with the most at stake to be assisted in working through the conflict in their own interests. Persons who use the language of conflict management and conflict regulation argue that they want to increase the abilities of parties to manage or self-regulate their conflicts themselves because if conflicts escalate, external agents or agencies will step in and try to bring the conflict within their own definitions of acceptable boundaries of social control. Then the parties with much at stake will lose control of the process.

The most commonly used of the terms is 'conflict management', though the others are occasionally used as peace workers and scholars find expedient. The least controversial and more widely used concept is 'conflict prevention' which refers to 'Actions, policies, procedures or institutions undertaken in particularly vulnerable places and times in order to avoid the threat or use of armed force and related forms of coercion by states or groups, as the way to settle the political disputes that can arise from the destabilizing effects of economic, social, political and international change. Conflict prevention can also include action taken after a violent conflict to avoid its recurrence' (Lund 1997:2-3). In other words, conflict prevention can take place at two levels in a typical conflict life cycle:

a. When there has not been a violent conflict in recent years, and before significant signals of violence [make] possible [the] escalation of sustained violent conflict, conflict prevention aims to keep a conflict from escalation; and

b. When there has been a recent violent conflict but peace is being restored, conflict prevention aims to avoid a relapse or re-igniting of violence (ibid.).

'Preventive diplomacy', the next concept, is the attempt to make official policy out of conflict prevention. The UN Secretary General, Boutros BoutrosGhali (1992) defined preventive diplomacy as 'action to prevent disputes arising between parties, to prevent existing disputes from escalating into conflicts and to limit the spread of the latter when they occur'.

Preventive diplomacy involves a number of activities: diplomatic, economic and social, military, politico-institutional, legal, judicial, normative- 
ethical, etc. in the same way that it employs many tools: negotiation, conciliation, mediation, human rights monitoring, democracy building, economic assistance or sanctions, military assistance or even preventive deployment. The larger tasks, according to Lund 1999:45), include:

- Suppressing violence;

- Removing the weapons through which violence may be carried out;

- Addressing the issues in dispute by engaging the parties in dialogue or negotiations;

- Creating or strengthening the procedures and institutions through which such negotiations can be regularized in permanent institutions such as governments;

- Alleviating the egregious socioeconomic conditions that provide tempting occasions for incitement to violence; and

- Modifying perceptions and feelings of mistrust and suspicion among the parties.

Situations determine which of these tools are most likely to be used in dealing with specific problems. The closer a conflict is to the violent stage the more likely is the use of the military to regulate weapons, engage in preventive deployment or enter into a defence alliance.

Closely related to the concept of preventive diplomacy as conceived by the UN Secretary-General are three other terms: peacemaking, peace-keeping and peace-building. Peacemaking refers to all action aimed at bringing hostile parties to agreement through peaceful means in consonant with Chapter VI of the UN charter. Peace-keeping 'is the deployment of the United Nations presence in the field, hitherto with the consent of all parties concerned, which normally involve United Nations military and/or police personnel and frequently civilians as well. Peace-keeping is a technique that expands the possibilities for both the prevention of conflict and the making of peace' (Boutros-Ghali 1992:11). On the other hand, peace-building is any 'action to identify and support structures which will tend to strengthen and solidify peace in order to avoid a relapse into conflict'.

Explaining the roles of each of these paradigms in the management of contemporary conflicts, Boutros-Ghali noted that:

Preventive diplomacy seeks to resolve disputes before violence breaks out; peacemaking and peace-keeping are required to halt conflicts and preserve peace once it is attained. If successful, they strengthen the opportunity for 
post-conflict peace-building, which can prevent the recurrence of violence among nations and peoples.

The last but by no means the least of the concepts we seek to sample in this paper is 'conflict reduction'. This refers to all activities associated with reducing the intensity of a conflict. Conflict reduction assumes that the conflict is inevitable but that its scale of escalation has to be controlled through some strategic decisions and measures. Conflict reduction can therefore manifest at any of the levels discussed above.

\section{Background to the AU mechanism for conflict management}

The Mechanism for Conflict Prevention, Management and Resolution (MCPMR) of the Organisation of African Unity (OAU) was established following a decision taken by African Heads of State during the 29th session of the Assembly of Heads of State and Government in Cairo in June 1993. The mechanism was incorporated as an organ of the African Union (AU) when it was established at the July 2001 Lusaka Summit. The OAU was formally dissolved on July 9, 2002 at the 38th ordinary session of the organization's Assembly in Durban, South Africa. The AU thereafter took over the rights, powers and obligations of the OAU. One of such obligations is that of conflict management.

The mechanism was preceded by a number of other attempts to find an appropriate formula for dealing with conflicts in Africa. It would be recalled that the Charter of OAU, at its creation in 1963 included the Commission of Mediation, Conciliation and Arbitration which was aimed at facilitating peaceful settlement of disputes between member states. The Commission whose activities were restricted to interstate conflicts was additionally vested with powers to investigate and inquire into the disputes brought before it. It is unfortunate that the Commission never become operational and had to be abolished. Several ad hoc committees (of heads of state and government, good offices, fact-finding etc.) had to be established to deal with the disputes that arose between member states. The UN was also involved in the management of some of the disputes. One of the shortcomings of these ad hoc arrangements is that they were reactive and remedial 'rather than proactive and preventative' (Naldi 2002: 98). MCPMR, on the other hand, seeks 'to bring to the processes of dealing with conflicts in our continent a new institutional dynamism, enabling speedy action to prevent or manage and ultimately resolve conflicts when and where they occur' (OAU 1993:13).

The Constitutive Act of the African Union (which replaced the Charter of the Organisation of African Unity) did not initially provide for any mechanism for conflict prevention, management and resolution. The OAU's MCPMR 
and the Cairo Agenda for Action on the MCPMR were not factored into the document. This has been attributed to the 'haste with which the drafters (of the Act) had to meet the impatient deadlines set by Libya' (Cilliers 2002). To rectify this, the objectives and principles of the Cairo Declaration were made an integral part of the declared objectives and principles of the AU, in accordance with Article 5(2) of the AU Act.

Against the background of the threat posed to African development by small arms proliferation, the AU also adopted a Protocol on the Establishment of the Peace and Security Council (PSC) of the AU to supersede all resolutions and decisions of the OAU on the MCPMR when it finally enter into force. ${ }^{2}$ The objectives of the PSC (as contained in Article 3 of the Protocol Establishing the Peace and Security Council of the African Union) are:

(a) promote peace, security and stability in Africa, in order to guarantee the protection and preservation of life and property, the well-being of the African people and their environment, as well as the creation of conditions conducive to sustainable development;

(b) anticipate and prevent conflicts. In circumstances where conflicts have occurred, the Peace and Security Council shall have the responsibility to undertake peace-making and peace-building functions for the resolution of these conflicts;

(c) promote and implement peace-building and post-conflict reconstruction activities to consolidate peace and prevent the resurgence of violence;

(d) co-ordinate and harmonize continental efforts in the prevention and combating of international terrorism in all its aspects;

(e) develop a common defence policy for the Union, in accordance with article 4(d) of the Constitutive Act;

(f) promote and encourage democratic practices, good governance and the rule of law, protect human rights and fundamental freedoms, respect for the sanctity of human life and international humanitarian law, as part of efforts for preventing conflicts.

The PSC establishes an operational framework 'for the effective implementation of the decisions taken in the areas of conflict prevention, peace-making, peace support operations and intervention, as well as peace-building and post-conflict reconstruction'.

The reasons for establishing both the MCPMR and the PSC are not dramatically different from why the OAU had to become the AU. The main 
objective is to reposition Africa for more effective participation in global politics and economy in the post-cold war world. During the cold war, African states were courted by both the East and West in their inordinate ambition to expand their spheres of influence. With the end of the cold war in the late 1980s, foreign investment and aid from the developed world to Africa declined sharply. The end of the cold war affects Africa in another significant way. As the two former superpowers seized the opportunity of the end of the cold war to manufacture new arms, the 'surplus' arms they stacked up during the cold war were channelled to the developing world, largely through black markets. The weapons fuelled intra-state civil disorder in different parts of the developing world, most especially Africa.

Most of the post cold war era conflicts in Africa are intrastate in nature. They took place within states rather than between them. The OAU which was formed to contend with the challenges of cold war conflict dynamics found it difficult to upgrade its systems to the standards needed for dealing with the intra-state conflicts of the post cold war era. This explains why most of the intra-state conflicts in Africa, except those that occurred in the West African sub-region, since the late 1980s were left to outsiders to deal with. When outsiders failed to come in, the OAU literally folded its hands and at best blame outsiders for not responding appropriately as the situation slid from bad to worse. The OAU transmuted to AU as part of the larger attempt of African leaders to adjust to the reality of the post-cold war world.

The attention that is now devoted to issues of conflict management by the AU derives from the realization that it is impossible for any society bedevilled by violent conflict to maximally benefit from political and economic globalization (Ibiek-Jonah 2001). Violent conflicts rank among the leading factors responsible for African underdevelopment. On February 7, 1993, The New York Times published a list of 48 existing and potential violent conflicts all over the world. The African countries on the list are Mauritania, Mali, Senegal, Togo, Nigeria, Burundi, Kenya, Zaire, Algeria and Egypt. Things have worsened in Africa since then with Liberia, Rwanda, Sierra Leone, Côte d'Ivoire, Guinea Bissau, Togo ravaged by different degrees of violent conflicts. These conflicts have led to destruction of lives and property. This kind of conflict situation and even the ones that have not escalated into war unduly divert the attention of the government from priority areas of development to the bloated task of 'internal maintenance of law and order'. About $\$ 300$ billion is believed to be spent on the war industry annually throughout the world (Boulding 1990:35). Africa gulped a sizeable percentage of such resources, which would otherwise have been spent on development projects. 
As the number of conflicts in Africa increased, the continent became more marginalized in global politics, economics, science and technology. It was within this framework that Ali Mazrui (1995:9) observed 'In global terms the African state has become increasingly marginalized and has been pushed into the ghetto of the world system' since the end of the cold war.

Philip Ndegwa warns not to see the revalorization and marginalization of African states in idle academic terms. It is not 'a kind of natural and harmless gradual reduction of contacts between African economies and the rest of the world. What the process actually involves is the deepening of the poverty of an already very poor people, widespread unemployment, political instability and other economic and social hardships' (1993:13). One is therefore not surprised that as far back as 1991, The Economist (1991:17) predicted what could be the implications of the resulting marginalisation:

With cold-war interests gone, it is tempting to forget Africa. Eastern Europe, and still useful clients such as Egypt, are clamouring for aid; recession in the rich world makes generosity harder. Besides, aid to black Africa has a depressing record. In the 1980s the region swallowed more than $\$ 100$ billion of it and defiantly got poorer...Perhaps money for Eastern Europe would be money better spent...Africa has a claim that is all its own. It is the world's poorest and most wretched continent. If it were not for the Gulf war, television screens would now be showing emaciated Africans, who are starving in even greater number this year than they did in 1985. Hollow eyes and matchstick limbs tug on comfortable people's consciences. The rich world would be less than human if it ignored the starving, so it had better be in business of making starvation less common.

More than The Economist envisaged in 1991, the western media, most especially the satellite televisions, now beam to the rest of the world almost on daily basis, pictures illustrating the unsavoury consequences of contemporary African development: anarchy on the streets, unrepentant warlords boasting of their exploits and threatening to cause more troubles, child soldiers brandishing the latest automatic weapons, dead bodies in different stages of decomposition of city streets, displaced persons carrying what is left of their belongings on their heads and trekking to wherever, futureless orphans in pensive mood, tons of relief material being ferried to the refugee camps and suchlike happenings all over the place.

The western world has not withdrawn completely from African conflicts. They have merely adopted a new approach, which the AU has to learn from. Both the UN and the US now encourage the use of 'preventive diplomacy' for managing conflicts in Africa and elsewhere. The policy of preventive diplomacy was first given official push at the 1992 meeting of the heads of state and governments of the United Nations Security Council. Participants 
at the meeting were enjoined to give future attention to 'analysis and recommendations on ways of strengthening...the capacity of the United Nations for preventive diplomacy, for peacemaking and for peacekeeping' (cited in Boutros-Ghali 1992:1). The Agenda for Peace, which the United Nations Secretary-General wrote shortly after in response to this challenge, contained a chapter on preventive diplomacy. The report was warmly received by the UN General Assembly in October 1992. Since then, different regional organizations and communities have been encouraged to practice preventive diplomacy as an alternative to engaging in expensive peacekeeping operations.

The attitude of the US to the practice of preventive diplomacy is a clear message to African leaders to find better ways of dealing with their internal problems before they degenerate into crises. America is unwavering in its resolve not to send ground troops to Africa for any combat operations. The US National Security Director, Anthony Lake (1993), affirmed in that 'in addition to helping solve disputes, we must also help prevent disputes... [and] place greater emphasis on such tools as mediation and preventive diplomacy'. President Clinton too promised in his mid-1994 speech on Africa to 'help African nations identify and solve problems before they erupt'. He also noted at the Summit of the leaders of the member nations of the Conference on Security and Cooperation in Europe in December 1994 that 'we must work to prevent future Bosnia' (Washington Post, June 28, 1994). It is within this framework that preventive diplomacy has become the main plank of the US policy towards Africa (Lund 1999:5). The MCPMR of the AU is a direct response to all these challenges.

\section{The guiding principles of the MCPMR}

The point is that the MCPMR of the African Union is a logical response to the many frustrations faced by Africa and Africans immediately the cold war ended. The mechanism is emphatic that the responsibility for dealing with African problems rests mainly with Africans. The document suggests that African leaders have now come to the realization that though the international community can actually provide support, it cannot be expected to take the lead in making, building and keeping peace in Africa. Africans need to take their future in their own hands. The guiding principles of the mechanism thus include the following:

(a) sovereign equality and interdependence among Member States of the Union;

(b) respect of borders existing on achievement of independence;

(c) participation of the African peoples in the activities of the Union; 
(d) establishment of a common defence policy for the African Continent;

(e) peaceful resolution of conflicts among Member States of the Union through such appropriate means as may be decided upon by the Assembly;

(f) prohibition of the use of force or threat to use force among Member States of the Union;

(g) non-interference by any Member State in the internal affairs of another;

(h) the right of the Union to intervene in a Member State pursuant to a decision of the Assembly in respect of grave circumstances, namely: war crimes, genocide and crimes against humanity;

(i) peaceful co-existence of Member States and their right to live in peace and security;

(j) the right of Member States to request intervention from the Union in order to restore peace and security;

(k) promotion of self-reliance within the framework of the Union;

(l) promotion of gender equality;

(m) respect for democratic principles, human rights, the rule of law and good governance;

(n) promotion of social justice to ensure balanced economic development;

(o) respect for the sanctity of human life, condemnation and rejection of impunity and political assassination, acts of terrorism and subversive activities;

(p) condemnation and rejection of unconstitutional changes of governments.

Member states are expected to be committed to uphold the principles of the Union and contribute to the promotion and maintenance of peace and security in Africa. This has to be demonstrated through readiness to participate in conflict resolution, peace-making and peace-building at regional and continental levels; willingness and ability to take up responsibility for regional and continental conflict resolution initiatives; contribution to the Peace Fund and/ or Special Fund created for specific purpose; respect for constitutional governance, in accordance with the Lomé Declaration, as well as the rule of law and human rights; having sufficiently staffed and equipped Permanent Mis- 
sions at the Headquarters of the Union and the United Nations, to be able to shoulder the responsibilities which go with the membership; and commitment to honour financial obligations to the Union.

\section{Strategic provisions of the MCPMR}

The issues addressed in this section call for a review of some of the concepts defined at the beginning of this paper: conflict prevention, preventive diplomacy, conflict reduction, conflict management, conflict resolution, peacemaking and peace-building. How does each of them apply to the conflict management mechanism of the AU?

As it has been implied in earlier part of this paper, preventive diplomacy, conflict reduction, and peace-building are all aimed at preventing upward spiral of conflicts. In this context, those who work towards conflict reduction or who build and construct peace blocks do nothing but engage in preventive diplomacy. To this end, we subsume conflict prevention, conflict reduction and peace-building under the sub-theme 'preventive diplomacy' in the table that follows. Peacemaking is a conflict management, conflict resolution, or dispute settlement strategy. While we may group the three concepts together, peacekeeping is a unique activity that cannot be lumped with the others and is thus treated separately in the table that follows.

We can now come back to the main question posed at the opening section of the paper: What are the provisions of AU mechanism for (1) preventive diplomacy (2) peacemaking (3) peacekeeping. Table 1 presents the picture that emerges from the MCPMR of the AU.

Most of the provisions in the AU conflict management mechanism illustrate the significance of preventive diplomacy and common security in dealing with post-cold war conflicts in Africa. Preventive diplomacy makes sense in this context against the background of the fact that conflict is patterned and thus predictable. It is obviously possible to see signs of impending conflicts and therefore checkmate it. Even natural disasters, the most complex aspect of environmental conflict, can be predicted and if the necessary preventive steps are taken the effects on man could be minimized if not completely eliminated. We believe that other human-created conflicts can in like manner be prevented. It however takes the entire global community to implement any effective programme of conflict prevention in the contemporary world. In January 1993, a group of distinguished scholars, diplomats and representatives of NGOs met in New York to discuss the possibility of preventive diplomacy in the modern world. 


\section{Table 1: Overview of Strategic Provisions in AU Mechanism}

Preventive Diplomacy/ Peacebuilding
- creation of conditions conducive to sustainable development;

- promotion of democratic practices, good governance, the rule of law, protection of human rights and fundamental freedoms, respect for the sanctity of human life and international humanitarian law by member states;

- Early warning system;

- Preventing and combating international terrorism;

- post-conflict disarmament and demobilization;

- post-conflict reconstruction;

- Promote and encourage democratic practices, good governance and the rule of law, protect human rights and fundamental freedoms, respect for the sanctity of human life and international humanitarian law;

- Report war crimes, genocide and crimes against humanity;

- Sanction unconstitutional change of government;

- Preventive deployment;

- Need to protect the environment;

- Cooperation with African regional and sub-regional organizations and neighbouring countries, etc

Conflict Management/

- Peacemaking through the use of good offices, Conflict Resolution/ mediation, conciliation and enquiry, etc.

- Peace support operations and intervention;

- Humanitarian action and disaster management;

- A common defence policy for the Union, etc.

The meeting noted inter alia that preventive action '...requires a global system in which the UN, regional organizations, states, NGOs and others cooperate to remove the root causes of conflicts and to prevent the emergence and escalation of conflicts' (Rupersinghe 1993:7). This is one of the reasons why the AU Constitutive Act calls for collaboration between the AU and subregional organisations as well as the UN in dealing with conflicts within Africa. 
The main objective of the AU Mechanism is thus the anticipation and prevention of conflict with a view to 'obviating the need to resort to the complex and resource-demanding peace-keeping operations, which our countries will find difficult to finance' (AU 2002:15). The AU mechanism calls for peacemaking where conflicts have already occurred. Civil or military observation groups may be deployed to facilitate this, but even then, the group's mission or mandate must be limited in scope and duration. Should the conflict further degenerate into violence the assistance of the UN has to be sought by the AU. The AU Mechanism also provides for post-conflict peacebuilding, which aims at ensuring that a 'resolved conflict' does not re-emerge.

The seriousness with which the AU considers the work of preventive diplomacy is readily attested to by some provisions of the Constitutive Act of the AU and the New Partnership for Africa's Development (NEPAD). While the Act strongly advocate for early warning signs monitoring, NEPAD provides for peer review mechanism as a way of controlling future conflicts. Early warning here means occurrences that suggest that a society could soon be plunged into a violent situation. What to monitor in this case is not just limited to social events, but also economic growth, environmental degradation, movement of people across international borders (even to countries outside Africa), trafficking in arms and ammunition, spread of diseases, etc. The African Peer Review Mechanism (APRM) of NEPAD is intended to subject the policies of African leaders to the scrutiny, criticism, pressure and potential censure of their peers (Zirimwabagabo 2002:1).

\section{Possible problems of implementing the mechanisms}

The MCPMR holds great promise for peace in Africa. As argued by African leaders at the 1999 Assembly of African Heads of State and Government, this AU mechanism 'is a valuable asset for our continent which must be nurtured and consolidated', it 'symbolizes the concrete resolve of our continent to fully assume its responsibilities'. The paradox, however, is that a conflict management mechanism, like the constitution of a country, does not implement itself; it has to be made effective by humans. It is thus one thing for the AU to have a near-perfect conflict management mechanism, it is another for the organisation to have the capacity to effectively put into practice such a mechanism. Herein lies the dilemmas and challenges for the future. What then are the foreseeable problems?

\section{Financial constraints}

The first problem is finance. How is the AU going to generate enough financial resources to implement its intricate security management system? The experience of the AU is instructive. So long as the AU member states (as 
witnessed under OAU) are not willing to meet their financial obligations to the organization, the responsibility for conflict management will remain largely borne by the international community. We can illustrate the point being made here with the example of the stalemated OAU peace-keeping force in Chad in 1981. It took the OAU a whole year, after the need had been expressed by the organization, to send an intervention force to the country. Even after deployment, the success of the force was limited by acute shortage of finance, military expertise and logistics. The troop had to be withdrawn prematurely in 1982 (Costa 1995:29). This kind of situation is worse than not intervening in a conflict at all. The conflicting parties simply interpreted the withdrawal as an indication that the conflict could not be resolved peacefully. Each of them invested more in the bloody encounter with the expectation that it would win.

During the 32nd summit of the OAU in July 1996 in Yaoundé, Cameroon, African leaders were told for the umpteenth times that the organization was in financial straits. Its expected budget for 1995/6 was only 32 per cent paid up meaning that about $\$ 18.6$ million was yet to be paid for the fiscal years. Arrears that members had to pay as at April 1996 stood at \$36.5 million (West Africa 15-16 July 1996:1088). On June 2, 1996, the Egyptian Foreign Minister, Amr Musa, noted that the OAU's conflict prevention committee was facing serious financial problems. The problem faced was so severe that the OAU itself could not hold any 'summit-level meeting' (IP News p.3). The AU, with its bloated programmatic and bureaucratic nature, is bound to face more financial problems.

It would be recalled that to be able to get OAU members to the meeting where the groundwork was done for the OAU to become AU, the Libyan leader, Colonel Muhammar Ghadafi had to sponsor some delegates to the meeting by paying up their outstanding dues. The interesting point to add to this is that Libya itself had not paid up its dues and had to do so quickly. It was clear to all and sundry that the intention of Ghadafi for paying up such arrears was to get the OAU to change by all means. Change to or for what? Libya is not going to help the states pay their debt for ever. Now that Libya is now back in the good book of the West how sure are we that the country will continue to be interested in providing financial support to the AU as it did in the past?

The African Union is quite conscious of this potential problem. This is why Article 23 of the Constitutive Act of the AU listed defaults in the payment of membership dues as one of the conditions under which a member state can be sanctioned. The sanctions against this kind of offence include 'denial of the right to speak at meetings, to vote, to present candidates for 
any position or post within the Union or to benefit from any activity or commitments therefrom'.

\section{Cross-border support for armed rebellion}

Another problem is that African leaders are suspicious of one another. It is very difficult to apply a conflict management mechanism under this kind of situation. Muhammar Ghadafi, who championed the transmutation of the OAU to the AU is known to have sponsored several dissident movements in Africa. He trained Charles Taylor of Liberia and Foday Sankoh of Sierra Leone in revolutionary warfare and armed them to launch military attacks on their respective countries (TGII 2001:119-20; Washington Post, June 18, 2000). The attack of Charles Taylor against Liberia took off from Côte d'Ivoire in 1989 with the support of President Houphouët-Boigny. Charles Taylor was also alleged to have sponsored a rebel attack on the forest region bordering Liberia and Sierra Leone in Guinea Bissau in September 2000. Corporal Foday Sankoh's Revolutionary United Front (RUF), with the full backing of Charles Taylor's National Patriotic Front of Liberia launched a rebellion against Sierra Leone from Bomaru and Sienga on March 23, 1991. Compaore's Burkina Faso is popularly believed to be a party to the present conflict in Côte d'Ivoire just as the Sudanese government is known to be part of the protracted conflict in Northern Uganda. How can these African leaders work together for the peace of Africa?

\section{Operational efficiency of national armies}

How well equipped or trained is the African military? We are asking this question against the backdrop of the fact that within a few weeks of any major insurgency in the continent, the rebels are close to the capital and the government forces are found scampering for safety in different directions. This was the situation in Liberia and Sierra Leone. The Northern part of Uganda is today occupied by the Lord Resistance Army. Northern and Western Côte d'Ivoire is comfortably occupied by the Forces Nouvelles (FN), 'the new armed forces'. The story is the same with Northern Sudan.

What does this suggest? Why are professional soldiers so easily humiliated by rebels who are often tagged 'rag-tag drunken fighters'. Is it because our soldiers are not trained? Trained in what? Guerrilla warfare? If yes, then we have to ask the question: who provided such more qualitative training to the guerrillas? The operators of AU's conflict management mechanism will continue to be engaged in fire brigade missions until they find proactive answers to all the questions raised above.

What the present situation suggests to me is that African governments do not seem to pay due attention to making their armies combat ready in terms 
of the provision of enough equipment and the inculcation of the right kind of motivation. Two things are possible if a thief breaks into one's house all the time. The first is that the doors to that house are not strong enough. The second is that the thief has a technology that is very efficient for breaking down doors. AU member states must learn to start by constructing strong doors in their houses. Strong armies are needed for implementing the AU Mechanism for conflict management as it is. Weak armies cannot implement it except the organization seeks to deceive itself.

Takwa Suifon, the Liaison Officer of the West African Network for Peacebuilding (WANEP-Accra) at ECOWAS argued, for example, in one of his papers that the reason why the FN rebels have been controlling some parts (northern and western) of Côte d'Ivoire is the persistent propaganda by the French media and the British Broadcasting Corporation (BBC) that the MPCI is sophisticatedly 'armed to the teeth'. The Ivorian government national army, the Forces armées nationales de Côte d'Ivoire (FANCI), are therefore scared of launching the much awaited 'Battle of Bouaké' because, according to Suifon, FANCI is 'ill-equipped and ill-prepared' (2003:13). It is abnormal to expect an ill-equipped and ill-prepared army to perform the kind of magic we expect from them. The conflicts in Africa will continue to escalate into crisis as long as political leaders in the continent continue to treat their military institutions and personnel with levity.

Those who offered to stake their lives for the security of their countries must be treated with respect. The AU Constitutive Act must be carefully 'edited' to reflect this stark reality that will go a long way at ensuring that the conflict management mechanisms of the organization work.

The security that Africa has in future will depend on the morale of those who are put in charge of our security. Are they being properly treated? African armies must be strengthened in terms of training and motivation. Those who lead the continent must also make rebellions less attractive by doing what is right for their society. Accountable regimes that respect equal access to wealth and that promotes equalitarian justice is bound to be supported by the people. Such a regime would side with the rebels by granting them safe passage or providing them support as we witnessed in different parts of the continent.

\section{Test cases of AU's ability to enforce its MCPMR}

\section{AU's response to the 'military coup' in Togo}

Most of the conflicts in post-cold war Africa have to do with attempts by groups and individuals to change governments unconstitutionally. This issue must be reflected in a paper of this nature that focuses on peaceful manage- 
ment of conflicts by the African Union. Decisions were taken on this issue by the OAU during its 36th Ordinary Session in Lomé, Togo in 2000 (OAU 2000). The issue was further discussed at the 38th Ordinary Session in Durban, South Africa in 2002 (AU 2002). The 2002 OAU/AU Declaration on the Principles Governing Democratic Elections in Africa, which reaffirmed the principles of democratic governance in the 2000 document asserts, inter alia, that '[d]emocratic elections are the basis of the authority of any representative government' and '[d]emocratic elections should be conducted: (a) freely and fairly; (b) under democratic constitutions and in compliance with supportive legal instruments; (c) under a system of separation of powers that ensures in particular, the independence of the judiciary; (d) at regular intervals, as provided for in National Constitutions; and (e) by impartial, all inclusive competent, accountable electoral institutions staffed by welltrained personnel and equipped with adequate logistics' (Ibid. II/4)

'Unconstitutional change' of government, according to the 2000 OAU Declaration refers to 'military coup d'état against a democratically elected Government; intervention by mercenaries to replace a democratically elected government; replacement of democratically elected governments by armed dissident groups and rebel movements; (and) the refusal by an incumbent government to relinquish power to the winning party after free, fair and regular elections'.

Article 23 of the Constitutive Act of the AU expects a state that engages in unconstitutional change of government to be sanctioned. The sanction includes 'denial of transport and communications links with other member states, and other measures of a political and economic nature to be determined by the Assembly'. A number of incremental steps are to be taken to achieve this objective. The first is for the AU Secretary General to immediately 'publicly condemn such a change and urge speedy return to constitutional order'. The second step is for the AU to 'also convey a clear and unequivocal warning to the perpetrators of the unconstitutional change that, under no circumstances, will their illegal action be tolerated or recognized by the OAU'. The Central Organ of the regional body is convened to formally condemn illegal transfer of power. After this, a six-month ultimatum is issued for the restoration of constitutional government. Meanwhile the unconstitutional government is suspended from participating in the Policy Organs of the OAU. If after the six-month constitutional authority has not been restored to the country, the declaration 'a range of limited and targeted sanctions against the regime that stubbornly refuses to restore constitutional order should be instituted' (AU 2000 par. 4-17) 
President Gnassingbé Eyadéma, the longest serving Head of State in Africa died on February 5, 2005, having ruled his country for about three and half decades. He seized power as a young sergeant in 1967 and was forced by the wind of democratization that blew across Africa as the aftermath of the collapse of communism as a political and economic ideology in the late 1980 s to organize a multiparty election in 1993. He was re-elected into office in 1998 and 2003 under questionable circumstances. As a result of the human rights violations that characterized the 1993 election, the European Union had to suspend aid to Eyadéma's Togo. The investigations conducted by the United Nations and OAU also showed that the 1998 election in Togo was a charade. The worst took place in 2003 when the constitution of the country had to be tinkered with to allow Eyadéma run for the third term (BBC News 5 February 2005:20.50 GMT).

Our interest in this aspect of the paper is not on the poor human rights records of President Eyadéma but the attempt to make his son to succeed him immediately after his death in February 2005. He would constitutionally have been succeeded by the Parliamentary Speaker, Fanbare Natchaba Outtara. The Togolese army and the ruling party, both of which did not want power to slip out of their hands, immediately closed the borders of Togo after Eyadéma died. This was first and foremost to prevent the Parliamentary Speaker, who was had travelled to France to come into the country. Eyadéma's son, Faure Gnassingbé, was quickly sworn in as successor to his father.

The international community saw what happened in Togo as nothing but a military coup d'état. Alpha Oumar Konaré, AU Commissioner, was emphatic in his condemnation of the development: 'What's happening in Togo needs to be called by its name: it's a seizure of power by the military, it's a military coup d'état'. The Togolese Communication Minister, Pitama Tchalla, denied the charge: 'How long do you expect us to wait where there is a power vacuum at the summit of the state?' (BBC News 11 February 2005: 16.46 GMT). The Army Chief of Staff, General Zakari Namdja, made the same statement. He too wondered what would have happened to Togo if the political vacuum that was created was allowed to have lasted too long. A European diplomat who spoke to Reuter News Agency on the matter seemed to have agreed with Tchalla when he noted that what the Togolese military did was simply a neat trick that cannot be legally characterized as a coup: 'It is a political manoeuvre that has now violated the constitution. One might feel manipulated but it is within the lines of the constitution' (cited by BBC News 11 February 2005). 
The Constitutive Act of the AU and the MCPMR are opposed to the unconstitutional manner power was transferred in Togo. As noted earlier, the regional organization recognizes democratic elections as the only basis of the authority of any representative government. To this end, the AU condemned the development in Togo immediately. The rest of the world saw the unfolding situation as a test case of the AU's ability to protect democracy and prevent future conflicts in Africa. Both the AU and ECOWAS threatened to impose sanctions on the new regime. The AU position has been strongly supported by the European Union, the United States of America and France. As the BBC News (11 February 2005: 16.46 GMT) argued, 'If Africa cannot ensure that rules are respected in poor and tiny Togo...there is little hope for the rest of the continent'.

All the steps taken by the AU are as specified in the MCPMR for dealing with unconstitutional governments. If the regime of Faure Gnassingbé was recognised by the international community, he would have organized a sham election as done in many other parts of Africa and 'legitimately' succeed his father and rule the country for at least two terms if he does not manipulate the constitution to get a third term as his father did. Those who try to protest during any of the elections would have been killed as the senior Eyadéma was said to have done during the 1993, 1998 and 2003 elections. The AU prevented this worst case scenario from happening. Following relentless international pressure championed by the AU, the embattled Faure Gnassingbé resigned from office on February 26, 2005 and was replaced by an interim leader, Abass Bonfoh, formerly the Deputy Speaker of the Togolese Parliament. This provided the opportunity for a rebirth of democracy in Togo. The opportunity does not seem to have been fully exploited as the new regime hurriedly organized a presidential election on April 24, 2005 as a result of which Faure was "constitutionally" returned to office as the President. The election was everything but free and fair. Over 500 people died as a result of the violent protests that greeted the announcement of the election results. More than 400,000 Togolese fled their country (Amnesty International 2005:1). The resignation with which the AU upheld the results of the election suggests that the regional body is yet to be on top of the democracy project in Africa

\section{The AU in Sudan}

How does the AU deal with member states unwilling to respect international peace agreements? The situations in Sudan are quite instructive. Even with the AU peacekeepers on ground, the government of Sudan continued to bomb the positions of the 'rebels'. The African Union (AU) claims in late January that about 100 people have been killed in a bombing raid by the 
Sudanese Government on villages in the western region of Darfur and had to formally accuse Sudan of breaking the ceasefire agreement it signed at the end of the end of the peace meetings between Khartoum and the Sudan Liberation Army (SLA) and the Justice and Equality Movement (JEM), the two main rebel movements in Darfur, have been taking place in Abuja since August 2004 (Daniel 2005). The last round of the peace talk ended in a deadlock in December 2004.

The issue was specially mentioned by President Olusegun Obasanjo in his opening remarks at the Abuja AU summit: 'We can't but condemn such carnage no matter what excuse may be raised to try to justify it'. On the other hand, the government of Sudan has been accusing the rebels of attacking and burning villages in the border region and it was within this framework that the Sudanese Foreign Minister, Mustafa Osman Ismail, rejected an earlier African Union ultimatum for government troops to withdraw from positions seized in a recent offensive against rebels in Darfur: 'The government military operations against the rebels will stop only if the rebels pull out of the areas they occupied after 8 April (when a first ceasefire was agreed) and refrain from launching attacks on civilians and public property...From a military point of view, this indicates an offensive, which, if launched, would be prejudicial to the peace process', the minister said (Aljazeera 2004). Intervention in this kind of situation is very delicate. Yet something must be done.

The refusal of the Sudanese government forces and the allied Janjaweed militia to stop attacking the rebels, burning and looting their villages is already creating credibility problems for the regional organisation. Melvin Foote, director of the Washington D.C.-based Constituency for Africa, told BlackAmericaWeb.com (2004) that just because Sudanese government defied the wishes of the AU does not mean that the world should write off the $\mathrm{AU}$; it is however a warning sign of what the future could look like. He observed that 'They're (the AU) a new thing ... This war in Sudan has been going on for 30 years and the Africa Union doesn't have all the resources in the world to respond to it...What's happening in Sudan goes beyond the scope of any immediate solution. If the Africa Union can demonstrate some capacity to resolve the conflict, or get it to some point where it can be managed, then I think it bodes well for the future'. Kenneth Roth, the Executive Director of Human Rights Watch (HRW) came to a similar conclusion in his 527-page report on 60 countries around the world. He called for a large, UN-authorised military force to protect lives in Sudan, most especially in the Darfur region. He blamed the United States and western governments for leaving the conflict to the AU, an organization he characterized as being new, with no resources and military experience to contend with the magnitude of problems in Sudan (Lobe 2005). 
Lobe argued however that the US has actually taken the Sudan situation to the Security Council of the UN but could not get enough support to from the global body to deal with the matter collectively. Some members of the council have vested interests in the conflict. China has substantial oil investment in Sudan and Russia is known to be making huge profits from arms sale to the country. It is thus difficult to get these countries to support anything but a peaceful settlement of the Sudan crisis. The records of gross human rights violations committed by the US in Iraq do not proffer it sufficient moral credentials to push through its case of genocide against the Sudanese government.

The AU Peacekeeping force in Sudan has not been able to respond militarily to the challenge posed by the government of Sudan. The AU force in Sudan cannot do anything about this until its mandate is beefed up, possibly to include more troops and the authorization to protect displaced people and humanitarian workers. The mandate of the mission, for now, is to monitor the peace process. It is not a peacekeeping mission per se. The AU monitors themselves are not protected and are only being protected by the Rwandese troops they met on ground.

The responsibility to disarm the fighters was not given to the AU monitors but to the government of Sudan. Instead of abiding by a United Nations mandate to disarm and disband Arab militias, which include Janjaweed fighters, Sudan's government is believed to still be recruiting them into police and civil defence forces. Both fight the non-Arab rebels together. Major General Festus Okonkwo of Nigeria, head of the AU's mission in Sudan, was recently reported to have accosted and seriously reprimanded a Sudanese army officer working with the mission, Lieutenant Colonel Asala, for phoning the Arab rebel commanders (Kabkabiyar 2004). As a result of this kind of lax security system, AU monitors have been ambushed on several occasions. On one of such occasions, an SLA commander and his four bodyguards were killed in an ambush by uniformed Janjaweed fighters, when he was escorting AU monitors to Zalingei, to negotiate the release of 18 Arabs kidnapped by SLA rebels.

The inability of the AU monitors to take any drastic action about the problems they encounter in Sudan derives from some 'defects' noticed in the MCPMR. As earlier noted, the emphasis of the mechanism is on preventive diplomacy; it does not give prime consideration to peacekeeping. In case of a violent conflict, what the MCPMR recommends is to send an AU civilian or military observation group and this, precisely, was what the AU Mission in Sudan is all about. The MCPMR recommends that such a monitoring group must be limited in scope and duration (AU 2002:15) and if unable to 
deal with the situation should seek the assistance of the UN. The monitoring group must be guided by the principles of sovereignty and territorial integrity of the state where the conflict is taking place and can only function on the basis of the consent and cooperation of the conflict parties (Cairo Declaration).

AU's efforts at bringing peace to Sudan got a boost on July 31, 2007 when a UN resolution was passed calling for 26,000 peacekeepers to be sent to the Western Darfur region of the country (Anita 2007; Khalilzad 2007). In its initial phase, the hybrid operation will draw its forces from the existing AU Mission in Sudan (AMIS) and from the UN Light and Heavy Support Packages of assistance to AMIS. The hybrid UN peacekeepers are given full authority under Chapter VII of the UN Charter to use force to protect civilians, facilitate the implementation of the Darfur agreement and prevent the kinds of armed attacks that sabotaged past efforts of AMIS to attain sustainable peace in Sudan. When fully operational, the force would provide a model on how the African Union can collaborate with the rest of the world in bringing peace to Africa.

\section{Notes}

1. The first draft of this paper was presented to participants of Course 13 of the National War College, Abuja, Nigeria. The comments of the course participants and command staff of the College, which have been included in this revised draft, are thankfully acknowledged.

2. The 15-member Peace and Security Council was established in May 2004. It is modeled after the UN Security Council, designed to address regional conflicts. Part of the work of the council is to facilitate the creation of an early warning mechanism for Africa, establish a 'Panel of the Wise' to troubleshoot, and put in place an African Standby Force with the capacity to intervene in any crisis within ten days.

\section{Bibliography}

Adedeji, A., 1993, 'Africa in a World in Transition: Laying the foundation for security, stability, structural transformation and co-operation', in Olusegun Obasanjo and Felix G.N. Mosha (eds.), Africa: Rise to Challenge, Otta: Africa Leadership Forum.

Adisa, J., 1996, The Comfort of Strangers: The Impact of Rwandan Refugees on Neighbouring Countries, Nairobi: UNCHS (Habitat) and IFRA, Ibadan.

African Union, 2005, Declaration on the Framework for an OAU Response to Unconstitutional Changes of Government, Assembly of Heads and Government, 36th Ordinary Session, OAU Doc. AHG/Decl.5 XXXVI, Lomé, 
Togo, 2000 (http://www.iss.co.za/AF/RegOrg/unity/pdfs/oau/hog/ 10HoGAssembly2000.pdf)

African Union (2002, Decisions on the Establishment of the Peace and Security Council of the African Union, AU Assembly, 1st Ordinary Session, A.U. Doc. ASS/AU/Dec. 3(1), Durban, South Africa (http://www1.umn.edu/humanrts/ Africa/audec1-8.html).

African Union, 2005, Priority Plan of Actions: Horizon 2007 (Rev.2) Volume 1, Addis Ababa: Commission of the African Union.

Aljazeera, 2004, 'Sudan Rejects AU Ultimatum' (http://english.aljazeera.net), 18 December.

Amnesty International, 2005, ‘Togo’s Election Leads to a Spiral of Violence', http:/ /web.amnesty.org/wire/June2005/Togo

Annan, K., 1999, ‘Two Concepts of Sovereignty’, The Economist, 18 September.

Anita, A., 2007, 'UN Force in Darfur Faces Challenges', VOA News, http:// www.voanews.com/english/2007-08-02-voa36.cfm

Berman, E., 2000, Re-armament in Sierra Leone: One Year After the Lome Peace Agreement, Occasional Paper Number 1, Geneva: Small Arms Survey.

Berman, E.G. and Sams, Katie, E., 2000, Peacekeeping in Africa: Capabilities and Culpabilities, Geneva and Pretoria: UNIDIR and ISS.

Boulding, K.E., 1990, Three Faces of Power, London: Sage.

Boutros-Ghali, B., 1992, Agenda for Peace, New York: United Nations.

Chimutengwende, C., 2003, 'Making the African Union Succeed', New African, June.

Cilliers, J. and Sturman, K., 2002, 'The Right Intervention: Enforcement Challenges for the African Union', African Security Review, Volume 11, Number 3.

Cilliers, J., 2002, 'Commentary: Towards the African Union', African Security Review, 10(2).

Commey, P., 2003, ‘Africa: The Union Takes Shape’, New African, June.

Darby, J., 1995, What's Wrong with Conflict? Coleraine: Centre for the Study of Conflict, University of Ulster.

Gibson, S., 1999, 'Beyond the War of Images: Towards Common Security and New Partnership with Africa', Lennart Wohlgemuth et al (eds.), Common Security and Civil Society in Africa, Uppsala: Nordiska Afrikainstitutet.

Howe, H., 1996/7, 'Lessons of Liberia: ECOMOG and Regional Peacekeeping', International Security, 21(13), pp.145-176.

Ibeike-Jonah, I., 2001, 'Transforming the OAU to African Union', Africa Notes, December.

International Crisis Group, 1998, 'Burundi under Siege: Lift the Sanctions; Relaunch the Peace Process’, Burundi Report, 18 April.

IRI Update for Central and Eastern Africa, No. 405, 8 April 1998. Integrated Regional Information Network for Central and Eastern Africa, United Nations Office for the Co-ordination of Humanitarian Affairs.

Jonah, O.C., 1993, 'Problems of Security in Africa', in Obasanjo and Mosha (eds.), Africa: Rise to Challenge pp.27-38 
Kanbur, R., 2002, ‘New Partnership for Africa’s Development', Africa Notes, March/ April.

Khalilzad, Z., 2007, 'Explanation of vote by Ambassador Zalmay Khalilzad, US Permanent Representative on the adoption of the hybrid force for Sudan, to the Security Council, July 31 2007', http://www.un.in/usa/07_184.htm

Kiplagat, B.A., 1995, 'The African Role in Conflict Management and Resolution', in David R. Smock and Chester A. Crocker (eds.), African Conflict Resolution: The US Role in Peacemaking, Washington: United States Institute of Peace.

Kiplagat, B., 1998, 'Is Mediation Alien to Africa?’, Track Two, 7(1) pp.4-7.

Kleiboer, M.A., 1997, 'International Mediation: The Multiple Realities of Thirdparty Intervention', Leiden, Department of Public Administration, Ph.D thesis.

Lake, A., 1993, Remarks Made by the US National Security Advisor to the Brookings Institution Africa Forum Luncheon, May 3.

Lobe, J., 2005, 'Report Singles Out US, Sudan for Strong Censure', http://www.net/ headlines.asp, January. Also available at http://www.commondreams.org/ headlines05/0113-11.htm

Lund, M.S., 1997, Preventing and Mitigating Violent Conflicts: A Revised Guide for Practitioners, Washington DC: Creative Associates International.

Lund, M.S., 1999, Preventing Violent Conflicts: A Strategy for Preventive Diplomacy, Washington, DC: United States Institute for Peace.

Maclean, W. 2004, ‘AU, Sudan Signal Differences over Darfur Security’, SPLM Today.com, http://splmtoday.com/modules.php?name=News\&new-topic=3, July 8.

Mahmoud, A. A., 1996, 'Somalia: An Alternative to Anarchy', West Africa, 29 July4 August.

Maluwa, T., 1989, 'The Peaceful Settlement of Disputes among African States, 1963-1983: Some Conceptual Issues and Practical Trends', International and Comparative Law Quarterly, Volume 38.

Menkhaus, K., 1996, 'International Peace-building and the Dynamics of Local and National Reconciliation in Somalia’, International Peacekeeping, 3(1) pp. 42-67.

Military Strategy Page, 2005, 'Sudan: Why the Bombers Continue to Bomb’, http:/ /www.strategypage.com/fryeo/qndguide/default.asp?target=egypt, February 5, 2005.

BlackAmericaweb.com, 2004, 'Sudan Defies Deadline, Continues Attack', (http:// www.blackamericaweb.com/), December 202004.

Moussa, A., 1994, 'Keynote Address: Supporting Africa's Own Initiatives for Peace', in Ocaya-Lakidi, Report on The Cairo Consultation: The OAU Mechanism for Conflict Prevention, Management and Resolution, New York: International Peace Academy.

Naldi, G.J., 2002, 'Future Trends in Human Rights in Africa: The increased role of the OAU', in Malcolm Evans and Rachel Murray (eds.), The African Charter on Human and Peoples' Rights: The System in Practice, 1986-2000. 
Nathan, L., 1998, 'A Case of Undue Pressure: International mediation in African civil wars', in African Mediation Seminar, Johannesburg: IMSSA, CCR in Cooperation with UNCHR.

Ndegwa, P., 1992, 'Africa and the World: Africa on its own', in Olusegun Obasanjo and Felix G.N. Mosha (eds.), Africa: Rise to Challenge, Otta: Africa Leadership Forum.

Ngate, J., 1996, ‘African Development: A Contradiction in Terms’, Africa Notes, November.

Nyakyi, A., 1998, Untitled paper presented at the Learning from Conflict Resolution in Africa Workshop in Arusha, 21-23 January.

OAU, 1993, 'Declaration of the Assembly of Heads of State and Government on the Establishment within OAU of a Mechanism for Conflict Prevention, Management and Resolution, Cairo, Egypt'.

OAU, 2000, Declaration on the Framework for an OAU Response to Unconstitutional Changes of Government, Assembly of Heads of State and Government, 36th Ordinary Session, OAU Doc. AHG/Decla.5 (XXXVI, Lome, Togo, 2000 (see http://www.africa-union.org/en/commpub.asp?ID=106)

Ocaya-Lakidi, D., 1996, Report of the Cairo Consultation: The OAU Mechanism for Conflict Prevention, Management and Resolution, New York: International Peace Academy.

Rothschild, E. and Wohlgemuth, L., 1999, 'Preface', in Lennart Wohlgemuth et al (eds.), Common Security and Civil Society in Africa, Uppsala: Nordiska Afrikainstitutet.

Rupersinghe, K., 1992, Internal Conflict and Governance, New York: St. Martins Press.

Rupersinghe, K., 1993, Early Warning and Preventive Diplomacy: A Discussion Paper, London: International Alert, February.

Rupersinghe, K., 1995, Conflict Transformation, London: Macmillan Press.

Rupersinghe, K., 1998, Civil War, Civil Peace: An Introduction to Conflict Resolution, London: Pluto Press.

Schmid, A.P., 2000, The Thesaurus and Glossary of Early Warning and Conflict Prevention Terms, London: Forum for Early Warning and Early Response.

Singer, K., 1949, 'The Resolution of Conflict', Social Research, VI, pp 230.

SPLM Today Com, 2005, 'AU Military Chief Caution Against Flop in Sudan', (http://splmtoday.com/modules.php?name=News\&new-topic=3)

Kabkabiyar, R.R., 2004, ‘AU Troops Struggle amid Sudan’s Fragile Ceasefire’, VOA News, 23 November.

Suifon, T.Z., 2003, 'Patriotic Rebels: West Africa's Architects of the New Patriotism', From the field, Accra: West African Network for Peacebuilding.

The Graduate Institute of International Studies, Geneva, 2001, Small Arms Survey 2001: Profiling the Problem, Oxford: Oxford University Press.

Udombana, N.J., 2002, 'The Institutional Structure of the African: A Legal Analysis', California Western International Law Journal, Volume 33, Number 1. 
Van Eck, J., 1997, 'Brokers in Burundi: Broadening the Nyerere mediation initiative', Track Two, 6(1).

Voutira, E. and Brown, S.A.W., 1995, Conflict Resolution: A Review of some nongovernmental practices, Uppsala: Nordiska Afrikainstitutet.

Washington Post, 1994, 'Clinton Urges New Policy Toward African Nations: Constituency must be built, conference told', June 28.

White, N.D., 1993, Keeping the Peace: The United Nations and the Maintenance of International Peace and Security, Manchester University Press.

World Bank, 1993, Sub-Saharan Africa: From Crisis to Sustainable Growth, Washington D.C.

Zirimwabagado, I., 2002, 'NEPAD’s Peer Review Mechanism - Our Brother’s Keeper', WITNEWS (http://www.scienceinafrica.co.za/2002/august/aprm.htm) Zoe, D., 2005, 'African Union Accuses Sudan of Ceasefire Violations', ABC Newsonline, Jan. 28. 